\title{
Youth marginalisation as a faith-based concern in contemporary South African society: Introducing a research contribution
}

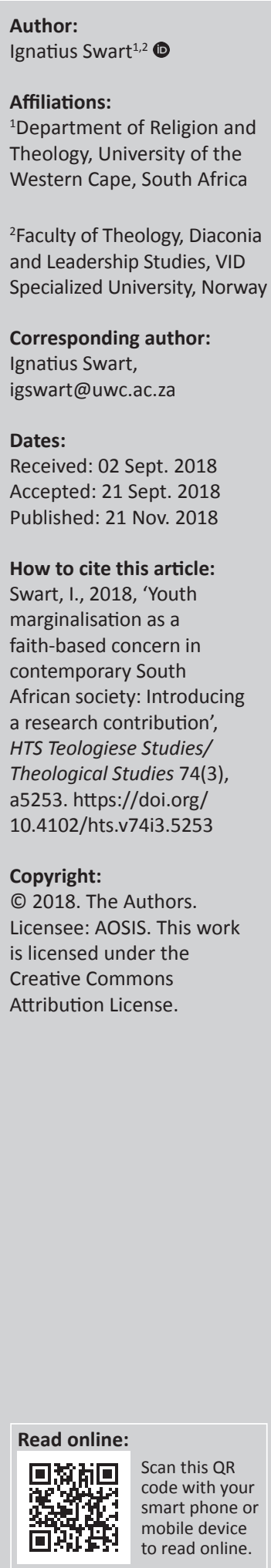

The aim of this article is to introduce a special collection of articles focused on the topic 'Youth marginalisation as a faith-based concern in contemporary South African society'. In meeting this aim the discussion begins by alluding to an international research project known under the acronym YOMA (Youth at the Margins: A Comparative Study of the Contribution of FaithBased Organisations to Social Cohesion in South Africa and Nordic Europe) as the source that inspired the undertaking of the collection. This recognition thereupon leads the article in subsequent sections to give some more detailed recognition to the YOMA project but also to a larger corpus of recent scholarly contributions as the most evident manifestations to date of an emerging South African research engagement with the topical focus under discussion. From this vantage point the article then proceeds to present the current special collection as a concerted attempt to give further momentum to the emerging focus. Importantly, however, this is done by presenting a more elaborate argument about the imperative of interdisciplinary engagement within the topical focus and how such engagement defines the nature and scope of the present collection. This finally leads the discussion to conclude with a summary of the contributing articles.

\section{Introduction}

The initiative to publish a special collection on the topic 'Youth marginalisation as a faith-based concern in contemporary South African society' in HTS Theological Studies was directly inspired by the international interdisciplinary team research project Youth at the Margins: A Comparative Study of the Contribution of Faith-Based Organisations to Social Cohesion in South Africa and Nordic Europe. Known under the acronym YOMA and funded by several sources that included the National Research Foundation (NRF) and Academy of Finland, ${ }^{1}$ this project formally ran from 2013 to 2016 under my co-leadership. From a specific South African interest, the project involved at its core case study research in four selected localities in the country ${ }^{2}$ exploring the manner and extent to which faith-based organisations (FBOs) touch the lives of so-called marginalised youth. These localities were the Pretoria Central areas in the City of Tshwane, eMakhazeni Local Municipality in the Mpumalanga Province, Franschhoek in the Western Cape and the extended neighbourhood of Riverlea on the outskirts of Johannesburg (Swart 2013:14-17).

One could well state that the YOMA project constituted a unique research undertaking at the time of its initiation, a fact that became clear to me during the initial literature research for the project proposal that had to be submitted to the NRF. Through my endeavour of searching for relevant material across the social science and theological disciplines, including those subdisciplines dedicated to a focus on youth-related research, I found, with the exception of one contribution, no evidence of a South African research focus combining an interest in faith-based or religious agency and the societal challenge of youth marginalisation (Swart 2013:11). Although not in the first place geared towards a research focus on FBO actors, the exception in this case was from my perspective, a contribution by a group of three researchers from the social sciences who wanted to describe a proposed programme to create sustainable employment opportunities for rural youth in South Africa. In doing so, I argued that the group of three researchers, by means of two publications in the early to mid-2000s (Everatt, Shezi \& Jennings 2005; Shezi, Everatt \& Jennings 2003), provided important support for the YOMA project's

1.The project was amongst others funded by the NRF and Academy of Finland based on a call to submit joint project proposals on the research theme of 'Children and Youth' in a number of priority areas.

2.Importantly, however, in terms of its comparative South African-Nordic interest the project also involved case study research in two Nordic localities: the Lammi rural community in Finland and the district of Søndre Nordstrand in Oslo, Norway (Swart 2013:17-19). 
research aim through their own 'appreciation of the agency role played by faith-based organisations to the problem of youth marginalisation' (Swart 2013:11).

In the aforementioned publications, the authors considered how a programme initiative developed around 'local faithbased structures' could reverse the growing failure of rural youth development in South Africa. In a post-1994 context where both the government or state and the market had failed to deliver on behalf of the country's rural youth, the three authors argued that rural-based faith-based structures had to be singled out for their 'high levels of youth participation' and for being 'less open to outside interference than many other organs of civil society' (Everatt et al. 2005:106; Shezi et al. 2003:115). To them, these features became clear from the results of their own research conducted in the Ugu District municipality in KwaZulu-Natal. It revealed that $\mathrm{FBOs}^{3}$ were outshining other civil society organisations by far in terms of their youth membership - their sample of FBOs scored $46 \%$, with burial societies a distant second at 15\% (Everatt et al. 2005:113; Shezi et al. 2003:119, 127-128). Furthermore, in addition to this quantitative argument, by upholding the example of a specific local church, they also argued that FBOs had to be valued 'for their particular ethos that emphasises the value of service.' They concluded that FBOs had thus emerged 'as one of the key vehicles for accessing rural youth', particularly unemployed and female youth ${ }^{4}$ (Everatt et al. 2005:109, 113; Shezi et al. 2003:119, 127-128).

It becomes important at this point, however, to qualify my argument somewhat. While some 5 to 6 years ago the publications by Shezi et al. and Everatt et al. were still providing the only important incentive to an anticipated South African research focus on the societal challenge of youth marginalisation from a more pointed faith-based concern, there are promising indications that this situation has started to change in recent years. This article, as part of the aim to introduce the aforementioned special collection of articles, continues in subsequent sections by giving some more detailed recognition to the YOMA project but also to a larger corpus of recent scholarly contributions as the most evident manifestations to date of such an emerging focus. From this vantage point the article then proceeds by presenting the current special collection as a concerted attempt to give further momentum to the emerging focus. Importantly, however, this is done by presenting a more elaborate argument about the imperative of interdisciplinary engagement with the topical focus and how such engagement defines the nature and scope of the

3.Whilst opting for the terms 'religious organisations' and 'faith-based structures, the three authors have refrained from becoming more specific about the fulle spectrum of institutional formations belonging to such organisations or structures. Although it remains unclear whether faith-based NGOs or institutions outside the Christian religious traditions were also implied, an explicit reference to Christian churches nevertheless surfaced. This included reference to the St John's Faith Mission Apostolic Church, an independent church of approximately 4 million members, but also a more, an independent church of approximately 4 million local church organisations' and 'churches' (see Everatt et al. 2005; Shezi et al. 2003).

4.Whilst upholding the figure of $46 \%$ of youth belonging to their sample of FBOs, the three authors significantly qualified this statistic. They highlighted the fact that young women were far more likely to belong to a religious organisation than young men - 55\% compared to 19\% (Everatt et al. 2005:113; Shezi et al. 2003:127). present collection. This finally leads the discussion to conclude with a summary of the contributing articles.

\section{The youth at the margins project: Some additional notes}

Based on how I have already given recognition to the YOMA project as the source that inspired the present special collection of articles, it seems necessary and appropriate to provide the readers of this collection with at least some additional notes about this project, its execution since its inception in 2013 and its unfolding contribution to the topical focus under discussion. In this respect, I could proceed from the background information already provided by describing the YOMA project as a team research undertaking that has not only been made possible by a new bilateral funding initiative (as already noted $)^{5}$ but importantly also by previous research collaboration across the South-North (South African-Nordic European) divide (see Swart et al. 2012a) ${ }^{6}$ that culminated in ever-growing network relationships between researchers from South Africa and the Nordic countries of Finland, Norway and Sweden. ${ }^{7}$ Through the YOMA project, therefore, a conscious effort would be made to build on the previous collaborative effort by engaging in an even more ambitious collaborative research undertaking between South African and Nordic researchers ${ }^{8}$ aimed at generating comparative perspectives and insights on a topical issue that was seen as having global relevance - the phenomenon of 'marginalised youth' in society - but added to this also the question about the nature and extent to which FBOs are involved in the lives of marginalised youths, in particular on the local level (see Swart 2013:1-5).

At the start of this article I pointed to the undertaking of case study research in four selected localities by the South African YOMA researchers as of special relevance to the South African focus of the present special collection. Yet, while this might imply that the comparative scope of the YOMA project across the Global South-Global North divide could be considered as less relevant to the direct purpose of the collection, this statement can also be relativised here when one considers how, in comparison to the aforementioned previous research collaboration the notion of 'difference' similarly surfaced as a prominent feature in the comparative findings of the YOMA research. Thus similar to the way in which the researchers from the previous research collaboration found it rather 5.See Footnote 1.

6.This collaboration, which was also made possible by bilateral funding and known as the WRIGP ('Welfare and Religion in a Global Perspective') project, mainly involved researchers from South Africa and the Uppsala Religion and Society Research Centre in Sweden. The final research outcome of this project is reflected in the anthology referenced in the corresponding main text above.

7. Here it could be mentioned how the WRIGP project enabled the South African project members (including myself) to connect to the research networks of the centre in Uppsala (see fn., 6), from which the YOMA project would directly benefit (see Swart 2013:4-5).

8.Twenty-one researchers from universities in Finland, Norway, Sweden and South Africa ultimately participated actively in the YOMA research and are contributors to the forthcoming anthology mentioned in this introductory article. Their respective disciplines included the fields of the sociology of religion, practical theology, systematic theology, missiology, youth work, sociology, anthropology, social policy, diaconal studies and development studies (with a focus on religion and development). 
difficult to draw any direct comparison with the Nordic countries when considering the far more extreme realities of poverty and its associated ills in the South African context (Swart et al. 2012b:12-13), researchers in the YOMA project have also highlighted their impression of difference in the light of their discovery of the far more expansive and severe nature of the problem of youth marginalisation in South African society. In this respect, I could uphold as an important case in point my own collaborative effort with two Nordic researchers to frame a contextual understanding of youth marginalisation for the project's case study research through exploring the concept of NEET - an acronym for 'young people not in education, employment and training' adopted internationally in academic and public debates about youth unemployment and marginalisation, including in South Africa and the Nordic countries. Through this exploration, we highlighted our impression of difference as follows:

The NEET concept has risen to prominence in research and the discourse on youth marginalisation in many different countries and contexts. It cannot be ignored - even if it is found wanting in certain respects, as pointed out in the European and Nordic discourse. When comparing contexts as different as the Nordic countries and South Africa, a case emerges for understanding the concept contextually, for example, through welfare theory ... The proportion of young people in NEET situations is so much greater in South Africa than in the Nordic countries, and the benefits and services available to them so different, that the life situations and needs of NEET young people are hardly directly comparable. This is also reflected in the differences between the Nordic and the South African discourses outlined in this article. In the Nordic countries NEET young people are primarily discussed as a problem in relation to the fiscal sustainability of the welfare state; in South Africa high NEET rates are discussed in relation to more fundamental issues such as social cohesion and social stability, racial and gender inequality, weak state performance and a dysfunctional education system. While the concept has been problematised as capturing heterogeneous populations in the Nordic countries, as in Europe more generally, it has rather been seen as capturing significant social and structural problems in South Africa. (Holte, Swart \& Hiilamo 2018:10-11; see also Swart, Holte \& Hiilamo 2018)

While further comparative analysis on the basis of the completed case study work on both the South African and Nordic sides is still ongoing as part of an anthology that will constitute the final, major outcome of the YOMA project, ${ }^{9}$ the preceding comparative statement nevertheless serves as a meaningful indicator as to why a research investment directed to the issue of youth marginalisation could be considered as even more urgent in the South African context than for example in the Nordic contexts. From the vantage point of a more pointed faith-based concern with such a research agenda, it could therefore be anticipated that the aforementioned completed South African case studies of FBO involvement in the lives of marginalised (NEET) youth will make a major research contribution as published chapters in the anthology in progress. Already available in final draft form (Hankela \& Nel 2018; Landman \& Yates 2018; Orsmond et al. 2018; Rabe, Swart \& De Beer 2018), these chapters are the outcome of extensive case study research in separate localities through the utilisation of the same quantitative research instruments in the form of interview guides for semi-structured interviews (individual and focus groups) conducted with young people and various resource people (such as FBO representatives) (cf. Swart 2013:21-22).

It would be premature for this article to engage in a more concerted discussion of the perspectives and findings that are presented in the different South African case study chapters and how those perspectives and findings contribute to a South African-Nordic comparative perspective on the topical focus. This, one should conclude, can ultimately only take place upon the publication of the anthology. At the same time, however, such qualification should not restrain one from observing how a strong case is being built through the South African YOMA case study research - both through the aforementioned chapter outcome and other emerging opportunities for publication ${ }^{10}$ that significantly include a number of contributions to the present special collection, ${ }^{11}$ of FBOs as a not insignificant presence in the lives of marginalised youth. In terms of further qualification, this evidence does not imply that the FBOs involved could not be criticised for their lack of involvement in the structural and political realities that have a direct bearing on the lives of marginalised youth. On the other hand, however, it does give insight into the way in which FBOs - which in the South African YOMA case study localities predominantly involved local churches and congregations and in some instances also faith-based NGOs linked to the Christian faith tradition ${ }^{12}$ often represent the last resort for marginalised youth in their struggles for everyday survival and subsistence, but also their yearnings for at least some experience of social cohesion and spiritual comfort, some sense of belonging and some escape from the hostilities of the outside world.

\section{Acknowledging a larger corpus of scholarly contributions beyond the youth at the margins project}

In the final paragraph of the introductory section of this article, I suggested that beyond the confines of the YOMA project it has become possible to also give recognition to a larger corpus of scholarly contributions that in recent years have in their own right started to give momentum to the topical focus of the present special collection. While at least in

10.For instance, one such opportunity for further publication recently arose through an invitation to contribute to an international book project on the subject of 'Youth, inequality and social change in the Global South'. Whilst this project was not explicitly geared towards a focus on FBOs in relation to the project theme, my co-authors (Marlize Rabe and Stephan de Beer) and I could fruitfully draw on the data generated through our YOMA case study research to make our contribution. Our accepted chapter contribution is entitled 'Hope for a better future: Young people's (im)mobility in Pretoria Central, South Africa'.

11.These are the articles by (1) Le Roux, Hankela and McDonald, (2) Rabe and (3) Landman and Yates in the special collection.

12.This identification suggests that the South African YOMA case study research (not surprisingly given Christianity's domination of the South African religious landscape) mainly led to an encounter with FBOs from the Christian faith tradition, that is, despite the YOMA project's openness towards all faith traditions in the that is, despite the YOMA project's openness towards all faith traditions in the
South African context, as pointed out elsewhere in this introductory article. See Footnote 19 and the corresponding main text in this article. 
one instance inspired by his participation as a member of the Riverlea case study in the YOMA project, here I could begin by acknowledging the foundational contribution of missiologist Reggie Nel, who explicitly dealt with the South African challenge of youth marginalisation from a faith-based concern in two of his articles published in 2014 and 2015. ${ }^{13}$ By locating himself very explicitly within a postcolonial epistemological paradigm, in these two articles Nel specifically concerned himself with the construction of methodological frameworks for urban public theological and missiological engagements with the contextual reality of youth marginalisation in contemporary South Africa. For him, in both instances of methodological construction, the agency or social movement role of youths themselves has to stand in the centre of how Christian churches or faith communities ought to relate to and support the contemporary youth struggles against marginalisation in South Africa. And in this sense, furthermore, an understanding of marginalisation and authentic FBO involvement has to be directly related to the 'new struggles' of young people themselves for identity, recognition and socio-economic opportunity in a postcolonial, neo-liberal context driven by global political economic and technological forces (Nel 2014; Nel 2015a).

While acknowledging Nel's foundational contribution towards establishing 'youth marginalisation' as a transdisciplinary topical focus in South African theological scholarship, I find good reason to also acknowledge a number of other contributions made in recent years as relevant to the establishment of such a focus. In these contributions, predominantly by a group of upcoming and younger scholars, the use of the term 'youth marginalisation' appears to be by and large absent. Yet, at the same time, they are in my view all meaningful for having begun to fill the void that Nel himself has aptly identified under the theological task of engaging with the realities of youth marginalisation as the prevailing 'lack of a deeper and broader framework for understanding ${ }^{14}$ the newer expressions of youth and student movements in the postcolonial context' of present-day South Africa (Nel 2014:6). Indeed, what characterises these contributions are a deepened and more pronounced social awareness of the contextual realities in which South African youth find themselves, a new emphasis on young people's experiences, voices and own roles as transformative agents in this context, and a concomitant new urgency to transform theological discourses, church structures and youth ministry models accordingly. In chronological order of publication, here I want to give recognition to Nadine Bowers Du Toit's (2014) theological concern with gangsterism on the Cape Flats and its effect on the lives of young people; Anita Cloete's (2015) theological reflection on youth unemployment in South Africa through the conceptual lens of human dignity; Shantelle Webers's (2015) articulation of a youth ministry research agenda that is more attuned to the cultural and social realities

13.The identification of these two articles does not suggest that other publications by $\mathrm{Nel}$ are not relevant to the combined topical focus. However, these articles are singled out for their explicit dealings with the notion of youth marginalisation in contemporary South African society.

14.Nel, in terms of this identification, includes 'the disciplines of practical theology systematic theology, youth ministry and even urban missiology' (p. 6). of young people in South Africa and Africa at large; Jacques Beukes and Marichen van der Westhuizen's (2016) exploration of the voices of children and youth in the URCSA ${ }^{15}$ Presbytery of Wellington in view of employing youth ministry strategies contextually more relevant to the needs and aspirations of those children and youth; Garth Aziz's (2017) consideration of youth ministry as an agency of development for vulnerable youth of the Cape Flats; Eugene Baron's (2017) interrogation of recent research findings on religious innovation and competition in the City of Tshwane in order to determine more closely the manner and extent to which church youth are involved in the transformation of the city; Shantelle Weber's (2017) closer reflection on the challenges and opportunities associated with the theological task of decolonising youth ministry models in Africa (and by implication South Africa); and, finally, Christina Landman and Hannelie Yate's (2017) adoption of 'Africanity' as a concept in research methodology to reflect on the results of their case study research about the relationship between the youth and FBOs in two townships in the eMakhazeni Local Municipality in Mpumalanga. ${ }^{16}$

\section{Nature and scope of the special collection}

Within the ambit of a still limited but not insignificant scholarly production relevant to the topical focus of the special collection, the recollection of a larger corpus of scholarly contributions meaningfully suggests that researchers from the disciplines of theology who, along with the YOMA project, have started to give momentum to this scholarly production. As my own literature research for the writing of this introductory article revealed, I could find no trace of a social science interest in the topical focus since the promising publications by Shezi et al. and Everatt et al., appreciated at the start of this article. ${ }^{17}$ In direct response, however, the present special collection seeks to address this lacuna in a conscious way and similar to the YOMA project includes scholarly contributions from both the theological and social science disciplines. As such, it marks a concerted attempt to include at least some members of the YOMA research team to contribute by drawing on the rich empirical data that were generated through their respective case study explorations. However, beyond these welcome contributions, the collection also marks a concerted attempt to include contributions by scholars outside the direct circle of YOMA researchers whose past and present research engagements testify about a dedicated concern with youth-related issues in the South African socio-economic and political context.

15.Uniting Reformed Church in Southern Africa.

16.As acknowledged in Footnote 3 of their article, Landman and Yates drew directly on their case study research for the YOMA project (see the first paragraph of this introductory article) to write their article.

17. My literature research also led me to the discovery of a recently completed PhD study in development studies by Mkwananzi (2017), which aimed to examine the everyday experiences and educational aspirations of marginalised migrant youth in Johannesburg. However, although the case study site for this study constituted the well-known Central Methodist Church (CMC) in the city and the Albert Street (AS) school linked to it, questions about the interaction between the CMC and AS school did not form part of the exploration (see pp. 6-7). The author has nevertheless been invited to contribute to the special collection (see the article by Mkwananzi and Wilson-Strydom in this collection). 
Taken together, what is offered is a special collection of articles that, similar to the YOMA project, ${ }^{18}$ is truly interdisciplinary in scope through the contributions of scholars from across the disciplines of systematic theology, ethics, practical theology, missiology, sociology, political science, social work, development studies and education.

This introductory article departs from a position that wants to celebrate the new momentum that South African scholars from the disciplines of theology are starting to offer in their own right to a research engagement that is relevant to the topical focus under discussion. This is indeed a promising development beyond the conventional preoccupation with issues of faith formation and the mobilisation of young people for the ministries of the church (cf. Nel 2015b:553-554; 2017; Weber 2017:5, 7, 8). At the same time, however, by upholding and promoting the importance of interdisciplinary contribution to the topical focus, the present collection of articles is by implication also steered by the conviction that the theological disciplines can only sufficiently deepen their own quest for deeper theoretical and empirical understanding of the subject matter ('Youth marginalisation as a faith-based concern in contemporary South African society') by becoming part of a larger interdisciplinary conversation and mode of collaboration. I want to start drawing this introductory discussion to a close by presenting two pertinent statements in support of this conviction.

Firstly, it should be considered as rather unconvincing that the theological disciplines and scholars from those disciplines dedicated to a more pointed social concern with the lives and well-being of South Africa's youth can on their own develop a level of conceptual and theoretical insight sufficient to come to terms with the phenomenon of youth marginalisation in contemporary South African society. Indeed, it is no exaggeration to state at this point that a concern with youth marginalisation, which could here be defined as a substantial section of young people's experience of 'structural isolation and lack of opportunities for development and participation (economic, political and social) in the post-apartheid democratic system' (Swart 2013:7), has shifted to the centre of social discourse in present-day South Africa. In a meaningful way, this is a development that I, as a member of the YOMA project, for instance, have learned more about through my own already mentioned exploration of the NEET concept and the way in which this concept has given new shape and direction to the academic and public debate about youth unemployment and marginalisation in present-day South Africa (see Holte et al. 2018:7-10; Swart, Holte \& Hiilamo et al. 2018). In a kairos-like manner, it is for instance through a greater acquaintance with this debate that one learns about a social concern of great urgency, hence commenting about South Africa's youth employment and NEET problem as perhaps the country's most urgent challenge, a 'national crisis' that seriously undermines its prospects for long-term social, economic and political stability (see, e.g., Altbeker \& Bernstein 2017; Butler-Adam 2013; Creamer 2013; DHET 2017; 18.See Footnote 8.
Kraak 2013; Lings 2013). In the words of one recent study, which seems worthwhile to quote at some length here (also as a complement to the more lengthy quote on the NEET concept earlier in this article):

At the end of 2016, there were just over 20 million young people (i.e. people aged between 15 and 34 years) in South Africa. Of these, 6.3 million were employed, 3.7 million were unemployed but looking for work (the definition of unemployment used to calculate the 'narrow' unemployment rate), 2.1 million were unemployed but were no longer looking for work (the 'discouraged' workers used when calculating the expanded rate of unemployment), and eight million were not economically active. Of those who were not economically active, five million were still in school and a million more were in some other form of educational institution or engaged in adult basic education. Overall, about 7.5 million young people (nearly $40 \%$ of all young people) were so-called 'NEETs' - not in employment, education or training ...

$[A]$ crisis of this scale is not just a matter of an economy wasting vast resources, but ... the social and political consequences are equally serious. Unemployed young people are much more likely to engage in undesirable activities, including criminality and substance abuse, and to become disruptive presences in their communities. The political consequences of a large cohort of young people who lack confidence in the ability of their society to provide them with employment and income they need to live their lives with dignity are also considerable. (Altbeker \& Bernstein 2017:1-2)

Secondly, the emphasis on the importance of interdisciplinary contribution is not meant to underplay the authentic contribution that the theological disciplines could make to the subject of youth marginalisation (for instance, Anita Cloete's contribution alluded to earlier in the discussion could be upheld as a meaningful case in point, i.e. the way in which she reflects on the problem of youth employment in South Africa through the lens of human dignity). Yet it is at the same time the willingness to engage in interdisciplinary conversation and collaboration that one could argue, creates the healthy possibility of broadening the parameters of a 'faith-based concern' with the realities of youth marginalisation, in South Africa but also elsewhere. Within such broadening, there still remains a prime opportunity for preoccupations with the agency role of the Christian church and the promotion of theological discourse in relation to the subject matter. Importantly, however, a wider space for reflection now also becomes possible, that others outside the disciplinary fields of Christian theology may feel more comfortable with as it not only allows for broader social and organisational categories of thinking but also accommodates greater interfaith sensitivity. This, then, is the operational framework that steered the YOMA project at least intentionally ${ }^{19}$ and has also been adopted for the purpose of the present special collection - even if the collection has through its limited scholarly participation only partly succeeded in meeting this operational framework. ${ }^{20}$ In a pertinent way, it is a framework that is closely associated 19.See Footnote 12 of this article.

20.Through the participation of one Muslim scholar, Zahraa McDonald, the special collection has at least taken a small step towards a broader interfaith engagement with the topical focus, amongst other objectives. 
with a rather open-ended working definition advanced in the international religion and development literature whereby the term $\mathrm{FBO}^{21}$ could be understood as any organisation that derives inspiration and guidance for its activities from the teachings and principles of a particular faith tradition or from a particular interpretation or school of thought within that faith (Clarke \& Jennings 2008:6; Swart 2013:9-10).

\section{Summary of a distinctive offer}

The special collection of articles on the topic 'Youth marginalisation as a faith-based concern in contemporary South African society' is published at a time when, as explicitly indicated earlier in this article, the process of finalising an anthology as the final, major outcome of the YOMA project ${ }^{22}$ is still ongoing. While it is anticipated that this anthology will make a noticeable contribution towards giving further momentum to what has been appreciated in this article as an emerging scholarly production relevant to this topical focus, it is hoped that the special collection of 11 articles (which includes this introductory article) will in a meaningful way add further weight to this momentum. I now conclude with a brief summary of the respective contributions that follow upon the introductory start made through this article.

Placed as second contribution in the collection, Sharlene Swartz and Anye Nyamnjoh's article fittingly takes us back to the starting point of engaging in empirical youth research. By drawing on a rich history of engagement in this area of research (in particular by Swartz), their contribution, which they also uphold as of significance for theological researchers, essentially involves a social justice concern with emancipatory qualitative research methodologies along what they identify as a 'continuum of interactive, participatory and emancipatory methods for addressing youth marginality.'

Following on Swartz and Nyamnjoh's contribution, the trio of Elisabet le Roux, Elina Hankela and Zahraa McDonald meaningfully continues the former's concern with social justice by drawing on their respective case study research in the YOMA project. Their theoretical engagement is essentially with two meanings of social cohesion in relation to how young people from the respective case study localities (Riverlea and Franschhoek) experienced the role of local churches in their everyday lives. This leads them to close with a rather strong conclusion about those churches' limited contribution to what they have highlighted as the social justice dimension of social cohesion.

In the fourth contribution to the collection, Marlize Rabe, another member of the YOMA project team, meaningfully shifts the focus of reflection to the roles of families and FBOs (under which she subsumes churches but also NGO-type

21.The term FBOs is commonly used in the religion and development literature and incorporates reference to a diverse range of religious organisations involved in one war way or another in development-related activities or work. One particular category in this diverse range of religious organisations (FBOs) includes reference to faith-based non-governmental organisations (faith-based NGOs) of a particular
faith-tradition (e.g. Islam, Catholic Church) involved in development-related work (see e.g. Jones \& Petersen 2011; Occhipinti 2015).

22.See Footnote 9 of this article. organisational formations) in the lives of marginalised young people. Her empirical context is the Pretoria Central case study from the YOMA project, which enables her to offer insightful perspectives on the separate but at times also interrelated roles of families and FBOs in the lives of marginalised youth in the case study area. This, in the final instance, includes a critical perspective on the limited role FBOs can play and are playing in the lives of marginalised youth in the case study area in the wake of weak state performance.

In the fifth article Christina Landman and Hannelie Yates conclude the contributions by YOMA researchers to the collection by drawing partly on findings from their YOMA case study research in Sakhelwe and Emthonjeni, two neighbouring townships in the deep rural eMakhazeni Local Municipality of South Africa's Mpumalanga Province. By also drawing on a fresh round of empirical research, their concern specifically lies with how the notion of 'respect' is understood by young people from these townships. In contrast to perceived dominant discourses amongst township youth that associate 'respect' with money, sex, violence and political activism, their article offers valuable insight into quite different perceptions amongst the interviewed youth of 'respect' as essentially a religious value and relational dynamics that related to their own yearnings for self-worth and respect the Christian churches in particular have to promote as a tangible asset through their teachings and social practice.

In the sixth article, Jacques Beukes and Marichen van der Westhuizen present a refreshing proactive angle to the discussion by not merely focusing on the reality of youth marginalisation in the present-day South African context. Instead, their primary concern lies with conceptualising an extensive proposal for the 'de-marginalisation of youths' in this context through a model of practice known as the Circle of Courage. This leads them to further propose the inclusion of 'Ubuntu principles' in the practical application of the Circle of Courage for churches and other FBOs.

In a similar proactive contribution, Faith Mkwananzi and Merridy Wilson-Strydom's focus in the seventh article falls on the use of the 'capability approach'23 as 'normative grounding' to analyse the case of AS School, a faith-based initiative ${ }^{24}$ that started to offer educational opportunities to a group of Zimbabwean migrant youths in the late 2000s in the city region of Johannesburg. By drawing on first-hand accounts of 12 migrant Zimbabwean youths who completed schooling at AS School, as well as those of other representatives, they conclude with a remarkable positive evaluation of how FBOs can meaningfully contribute to human development and capability expansion for marginalised youth.

While remaining with the theme of education, Zahraa McDonald's contribution in the eighth article stands out for

23.This is an approach to human development that has been widely popularised in the work of Amartya Sen, as the two authors (Mkwananzi and Wilson-Strydom) explicitly observe at the beginning of their discussion.

24.See also the brief background information provided in Footnote 17 of this introductory article. 
realising the interfaith aspirations of the collection, at least in a single article. By drawing on data gathered during an ethnographic study, her specific concern lies with the nature and extent of young South African Muslim women's education within a dynamic known as the Deobandi Islamic movement. She meaningfully concludes by upholding the Deobandi movement as a noticeable case of how FBOs can simultaneously contribute to the 'social inclusion' and 'marginalisation/exclusion' of young people in larger society, with particular reference to young Muslim women.

In the ninth contribution to the collection, Shantelle Weber and Nadine Bowers Du Toit shift the focus to the very acute and disturbing issue of sexual violence, particularly against female children and youth on the Cape Flats. They advance the thesis that such abuse takes place within an 'ecosystem of violence' that also severely affects the faith formation of the abused. From this vantage point they are especially concerned with the question of how local congregations on the Cape Flats can better respond by addressing the problem through proactive engagement.

In the penultimate contribution, John Klaasen brings yet another angle to the discussion by advancing a perspective on how young people could also be 'marginalised' as a result of the workings inside the church. His bone of contention specifically lies with the 2017 resolutions of the Anglican dioceses in the Western Cape and how the nature and outcome of those resolutions validate his standpoint, despite the apparent concern of the Anglican Church in the region with the plight of its youth. This identification subsequently leads him to argue for the adoption of a missional approach to youth ministry to address the marginal position of the youth and youth ministry in the church.

Finally, in another overt theological engagement with the topical focus, Johannes Knoetze's concern specifically lies with the plight of South Africa's 'marginalised millennials' young people between the ages of 15 and 35 years, who he recognises, not only constitute the majority of the population but also a prominent segment of the socially, economically and educationally marginalised in South African society. In similar fashion to Klaasen, Knoetze also takes a critical position against the Christian church's failure to challenge the systemic conditions of marginalisation and thereupon proceeds to adopt a missional church perspective in view of a more appropriateChristian response. For him, operationalising such a perspective especially entails upholding the binary concepts of 'conversation' and 'conversion' to challenge both the church and millennials in view of desired transformed behaviour and social change.

\section{Acknowledgements Competing interests}

The author declares that he or she has no financial or personal relationships which may have inappropriately influenced him or her in writing this article.

\section{References}

Altbeker, A. \& Bernstein, A., 2017, No country for young people: The crisis of youth unemployment and what to do about it, Centre for Development and Enterprise, Johannesburg, viewed 12 August 2018, from www.cde.org.za/wp.../2017/.../CDEEU-publication-No-country-for-young-people.pdf

Aziz, G., 2017, 'Youth ministry as an agency of youth development for the vulnerable youth of the Cape Flats', Verbum et Ecclesia 38(1), a1745. https://doi. org/10.4102/ ve.v38i1.1745

Baron, E., 2017, 'The role of church youth in the transformation agenda of South African cities', HTS Teologiese Studies/Theological Studies 73(3), a4771. https:// doi.org/10.4102/hts.v73i3.4771

Beukes, J.W. \& Van der Westhuizen, M., 2016, 'Exploring the voices of children and youth: A plea for renewal in church structures for child and youth ministries', Stellenbosch Theological Journal 2(2), 111-130. https://doi.org/10.17570/stj.2016. v2n2.a06

Bowers Du Toit, N.F., 2014, 'Gangsterism on the Cape Flats: A challenge to "engage the powers"', HTS Teologiese Studies/Theological Studies 70(3), Art. \#2727, 7 p. https://doi.org/10.4102/hts.v70i3.2727

Butler-Adam, J., 2013, 'Generation J', South African Journal of Science 109(5/6), Art. \#a0021, 1 p. https://doi.org/10.1590/sajs.2013/a0021

Clarke, G. \& Jennings, M., 2008, 'Introduction', in G. Clarke, M. Jennings \& T. Shaw (eds.), Development, civil society and faith-based organizations: Bridging the sacred and the secular, pp. 1-16, Palgrave McMillan, Basingstoke.

Cloete, A., 2015, 'Youth unemployment in South Africa: A theological reflection through the lens of human dignity', Missionalia 43(3), 513-525. https://doi org/10.7832/43-3-133

Creamer, T., 2013, “'NEETs crisis” emerging as SA's most urgent challenge', Engineering News, 25 June, viewed 26 August 2018, from http://www.engineeringnews.co.za/ article/neets-crisisemerging-as-sas-most-urgent-challenge-2013-06-25

Department of Higher Education and Training (DHET), 2017, Fact sheet on 'NEETs', DHET, Pretoria, viewed 26 August 2018, from www.dhet.gov.za/.../Fact-sheet-onNEETs-Final-Version-27-Jan-2017.pdf.

Everatt, D., Shezi, S. \& Jennings, R., 2005, 'An attempt to reverse the failure of rura youth development in South Africa', in H. Helve \& G. Holm (eds.), Contemporary youth research: Local expressions and global connections, pp. 103-120, Ashgate, youth resear.

Hankela, E. \& Nel, R., 2018, “'Keep yourself busy": Young people, FBOs and social cohesion in Riverlea', Unpublished chapter submitted for the YOMA project manuscript in preparation, in Stuck in the margins? Young people and faith-based manuscript in preparation, in Stuck in the margins?
organisations in South African and Nordic localities.

Holte, B.H., Swart, I. \& Hiilamo, H., 2018, 'The NEET concept in comparative youth research: The Nordic countries and South Africa', Journal of Youth Studies. https:// doi.org/10.1080/13676261.2018.149640

Jones, B. \& Petersen, M.J., 2011, 'Instrumental, narrow, normative? Reviewing recent work on religion and development', Third World Quarterly 32(7), 1291-1306. https://doi.org/10.1080/01436597.2011.596747

Kraak, A., 2013, 'State failure in dealing with the NEET problem in South Africa: Which way forward?', Research in Post-Compulsory Education 18(1-2), 77-97, https:// doi.org/10.1080/13596748.2013.755819

Landman, C. \& Yates, H., 2017, 'Africanity and research: A case study in rural South Africa', HTS Teologiese Studies/Theological Studies 73(4), a4775. https://doi.org/ 10.4102/hts.v73i4.4775

Landman, C. \& Yates, H., 2018, 'Do the FBOs know where they are going? Listening to the voices of rural youth in the eMakhazeni Local Municipality', Unpublished chapter submitted for the YOMA project manuscript in preparation, in Stuck in the margins? Young people and faith-based organisations in South African and Nordic localities.

Lings, K., 2013, 'Youth unemployment is a national crisis', Standpoint 2(2013), 7-8, viewed 26 August 2018, from http://www.stanlib.com/Advisers/Documents/ Business_Update/STANDPOINTVol22013.pdf

Mkwananzi, W.F., 2017, 'Exploring the lives and educational aspirations of marginalised migrant youth: A study in Johannesburg, South Africa', PhD in Development Studies, University of the Free State, Bloemfontein, viewed n.d., from http://hdl. handle.net/11660/6485

Nel, R.W., 2014, 'Discerning the role of faith communities in responding to urban youth marginalisation', HTS Teologiese Studies/Theological Studies 70(3), Art. \#2743, 8 p. https://doi.org/10.4102/hts.v70i3.2743

Nel, R.W., 2015a, 'Social media and the new struggles of young people against marginalisation: A challenge to missional ecclesiology in Southern Africa', Stellenbosch Theological Journal 1(2), 511-530. https://doi.org/10.17570/stj. 2015.v1n2.a24

Nel, R.W., 2015b, 'Remixing interculturality, youth activism and empire', Missionalia 43(3), 545-557. https://doi.org/10.7832/43-3-124

Nel, R.W., 2017, 'Everyday life, everyday connections? Theological reflections on the relevance of international youth studies research', HTS Teologiese Studies/ Theological Studies 73(4), a4627. https://doi.org/10.4102/hts.v73i4.4627

Occhipinti, L.A., 2015, 'Faith-based organizations and development', in E. Tomalin (ed.), The Routledge handbook of religions and global development, pp. 331-345, Routledge, New York.

Orsmond, E., Cloete, A., Le Roux, E. \& McDonald, Z., 2018, 'NEET young people in Franschhoek: A story of continued separateness', Unpublished chapter submitted for the YOMA project manuscript in preparation, in Stuck in the margins? Young people and faith-based organisations in South African and Nordic localities. 
Rabe, M., Swart, I. \& De Beer, S., 2018, “"Eish! It is tough living here": Marginalised youth and FBOs in Pretoria Central', Unpublished chapter submitted for
the YOMA project manuscript in preparation, in Stuck in the margins? Young people and faith-based organisations in South African and Nordic localities.

Shezi, S., Everatt, D. \& Jennings, R., 2003, 'Stuck in the margins? An attempt to reverse the failure of rural development in South Africa', Development Update 4(1), 113-139.

Swart, I., 2013, 'Youth at the margins: Introducing a new research initiative in an ongoing south-north collaboration in the context of international diaconia', Diaconia: Journal for the Study of Christian Social Practice 4(1), 2-26.

Swart, I., Gouws, A., Pettersson, P., Erasmus, J. \& Bosman, F. (eds.), 2012a, Welfare, religion and gender in post-apartheid South Africa: Constructing a South-North dialogue, Sun Press, Stellenbosch.
Swart, I., Gouws, A., Pettersson, P., Erasmus, J. \& Bosman, F., 2012b, 'Introduction', in I. Swart, A. Gouws, P. Pettersson, J. Erasmus \& F. Bosman (eds.), Welfare, religion and gender in post-apartheid South Africa: Constructing a South-North dialogue, pp. 9-24, Sun Press, Stellenbosch.

Swart, I., Holte, B.H. \& Hiilamo, H., 2018, 'NEET as a comparative conceptualisation of youth marginalisation: A South African-Nordic European exchange of perspectives', Unpublished chapter submitted for the YOMA project manuscript in preparation in Stuck in the margins? Young people and faith-based organisations in South African and Nordic localities.

Weber, S., 2015, 'A (South) African voice on youth ministry research: Powerful or powerless?', HTS Teologiese Studies/Theological Studies 71(2), Art. \#2973, 6 p. https://doi.org/10.4102/hts. v71i2.2973

Weber, S., 2017, 'Decolonising youth ministry models? Challenges and opportunities in Africa', HTS Teologiese Studies/Theological Studies 73(4), a4796. https://doi.
org/10.4102/hts.v73i4.4796 